\title{
C-Reactive Protein in the Diagnosis of Community-Acquired Pneumonia
}

Henry I. Z. Requejo and Ana Maria Cocoza

\author{
Adolfo Lutz Institute, Child Institute oh Clinical \\ Hospital of Univesity of São Paulo, São Paulo, SP, \\ Brazil
}

\begin{abstract}
Qualitative determination of C-reactive protein (CRP) was evaluated as a diagnostic method for community-acquired pneumonia. Paired serum and pleural fluid samples from child patients were examined with a CRP test, compared to bacterial cultures, counterimmunoelectrophoresis and immunoassay. The CRP test gave excellent parameters of sensitivity, specificity and predictive values for the diagnosis of bacterial pneumonia.

Key Words: C-reactive protein, community-acquired pneumonia, children.
\end{abstract}

C-Reactive protein (CRP) is an acute phase protein, synthesized by the liver in response to various stimuli [1]. The induction of CRP synthesis is triggered by a number of cytokines that are released into the inflammatory region, chiefly the pyrogenic cytokine interleukin-6 (IL-6). Fibroblasts, lymphocytes, promyelocytes and active macrophages are sources of IL-6[2,15]. CRP levels are higher in inflammatory pleural effusions than in other types of effusion $[5,9,16,22]$.

Most severe pneumonia episodes in childhood are caused by Streptococcus pneumoniae and Haemophilus influenzae type b (Hib). Nowadays, as a consequence of effective vaccination against $\mathrm{Hib}, S$. pneumoniae has become the only significant bacterial cause of community-acquired pneumonia in preschool age, normal healthy children [6-10]. Differentiation between viral and bacterial pneumonia, if possible, would be of utmost importance for clinicians. In young children, the most important problem is how to differentiate between pneumonias caused by respiratory virus versus $S$. pneumoniae. Moreover, mixed infections caused by virus and bacteria, especially by

Received on 17 January 2003; revised 23 May 2003.

Address for correspondence: Dr. Henry I. Z. Requejo, Instituto Adolfo Lutz, Seção de Imunologia. Av. Dr. Arnaldo 355, 01246902, São Paulo, SP, Brazil.

The Brazilian Journal of Infectious Diseases 2003;7(4):241-244 (C) 2003 by The Brazilian Journal of Infectious Diseases and Contexto Publishing. All rights reserved. respiratory syncytial virus and pneumococci, are common $[7,8]$. Since the assessment of the specific microbial aetiology of pneumonia is difficult, nonspecific inflammatory parameters and the type of infiltration in a chest radiograph are widely used for this purpose [6]. Serum samples for the determination of CRP concentration have been more useful than other materials, such as pleural effusion, for differentiation between bacterial and viral pneumonia in children [8]. The basic principle of the test is that when the fluid sample is mixed with the antiserum solution, the CRP reacts specifically with anti-human CRP antibodies to yield insoluble aggregates. The light absorbance of these aggregates in the sample is proportional to the concentration of CRP [12,16].

We studied the diagnostic value of CRP in bacterial pneumonia, especially regarding S. pneumoniae and Hib aetiology.

\section{Materials and Methods}

Paired serum and pleural effusion samples from 265 child patients were analyzed for CRP. The samples were centrifuged at $2000 \mathrm{~g}$ for $10 \mathrm{~min}$. to remove blood and other matter. Bacterial cultures (BC) were made from the pleural effusion samples. Counterimmunoelectrophoresis (CIE) and dotenzyme-linked immunosorbent assays (Dot-ELISA) were performed on the paired pleural fluid and serum 
Table 1. Results of comparative bacterial culture (BC), counterimmunoelectrophoresis (CIE), Dot-ELISA and C-reactive protein (CRP) assays for 265 paired pleural fluid and serum samples

\begin{tabular}{|c|c|c|c|c|c|c|c|}
\hline \multirow[t]{2}{*}{ Antigens } & \multicolumn{4}{|c|}{ Pleural fluid samples } & \multicolumn{3}{|c|}{ Serum samples } \\
\hline & BC & CIE & Dot-ELISA & CRP & CIE & Dot-ELISA & CRP \\
\hline Streptococcus pneumoniae & 40 & 51 & 68 & 68 & 21 & 24 & 24 \\
\hline Haemophilus influenzae $b$ & 12 & 22 & 36 & 36 & 7 & 13 & 13 \\
\hline Staphylococcus aureus & 6 & 6 & 6 & 6 & 6 & 6 & 6 \\
\hline Neisseria meningitidis & 1 & 1 & 1 & 1 & 1 & 1 & 1 \\
\hline $\operatorname{Unknown}(*)$ & - & - & - & 25 & - & - & 28 \\
\hline Total & 59 & 80 & 111 & 136 & 35 & 44 & 72 \\
\hline
\end{tabular}

(*) samples with negative BC and immunological tests, but with a positive CRP.

Table 2. Evaluation of the use of C-reactive protein (CRP) in the diagnosis of 265 paired pleural fluid and serum samples compared to the (BC + CIE + Dot-ELISA) tests for pleural fluid and (CIE + Dot-ELISA) for serum samples (given as percent concordance)

\begin{tabular}{lcr}
\hline Parameters & Pleural fluid & Serum \\
\hline Sensitivity & 100.0 & 100.0 \\
Specificity & 87.8 & 87.3 \\
positive predictive value & 81.6 & 61.0 \\
Negative predictive value & 100.0 & 100.0 \\
Prevalence & 42.0 & 16.6 \\
Accuracy & 91.0 & 89.5 \\
\hline
\end{tabular}

samples, according to routine procedures [17,18]. CRP was detected using a latex-agglutination test in which a suspension of latex particles sensitized with specific antiCRP antibodies agglutinates in the presence of an acute phase protein. This semiquantitative test detects 6 to $250 \mathrm{mg} / \mathrm{L}$ of CRP (Ebram Lab. Products Ltd, S. Paulo).

Diagnostic parameters, such as sensitivity, specificity and predictive values [4] and the kappa (k) concordance index [3] for CRP were evaluated in comparison with the gold standard tests, BC, CIE and Dot-ELISA for bacterial antigen detection $[17,18]$.

\section{Results}

Among the 265 pleural fluid samples from children with suspected community-acquired pneumonia, 59 (or
22 percent) gave a positive BC, 40 being $S$. pneumoniae, $12 \mathrm{Hib}, 6 \mathrm{~S}$. aureus and a single case of Neisseria meningitidis C. All these positive pleural fluid cultures were positive in the CRP test. The 77 negative pleural fluid cultures were also positive for CRP (Total: $59+77=136$ positive CRP pleural fluid samples) (Table 1). When all (BC+CIE + Dot-ELISA) tests were considered, 111 positive results were obtained and the following parameters were reached: sensitivity equal to $100 \%$, specificity equal to $87.8 \%$, and positive and negative predictive values equal to $81.6 \%$ and $100 \%$, respectively (Table 2). A kappa (k) concordance index of 0.82 (almost perfect concordance) with $\mathrm{Zo}=10.25(\mathrm{Zc}=1.96 ; \mathrm{p}<0.001$ for the $95 \%$ confidence interval) was obtained for the CRP-pleural fluid test in comparison with the $\mathrm{BC}+$ CIE + Dot-ELISA) tests. 
Among the 265 serum samples from the same patients, CIE and Dot-ELISA gave 44 positive tests and CRP gave 72 positives. The following parameters were obtained for these serum samples: sensitivity equal to $100 \%$, specificity equal to $87.3 \%$ and positive and negative predictive values of $61 \%$ and $100 \%$, respectively (Table 2). A substantial kappa concordance index of 0.70 with $\mathrm{Zo}=4.63$ for $\mathrm{Zc}=$ $1.96, \mathrm{p}<0.001$; for the $95 \%$ confidence interval) was obtained for the CRP test of the total serum samples.

\section{Discussion}

Several studies have suggested C-reactive protein concentrations of $20 \mathrm{mg} / \mathrm{L}$ or $40 \mathrm{mg} / \mathrm{L}$ as a screening limit for bacterial infections $[5,13,14]$. Considering the concentration limit $>40 \mathrm{mg} / \mathrm{L}$ to differentiate between viral and bacterial respiratory infections, Korppi and Kroger [8] found the best positive and negative predictive values of 0.76 and 0.55 , respectively, to support the presence of bacterial pneumonia. Turay et al. [21] found for pleural fluid CRP levels $>30 \mathrm{mg} / \mathrm{L}$, a sensitivity of $93.7 \%$, a specificity of $76.5 \%$ and a positive predictive value of $98.4 \%$, when these authors screened inflammatory pleural effusions. However, the definitive value of CRP for the differentiation between viral and bacterial respiratory infections has thus far remained unresolved $[8,19]$. Although pleural fluid CRP levels may be used to discriminate parapneumonic effusions from other types of exudative effusion, a CRP level above $30 \mathrm{mg} / \mathrm{L}$, highly suggestive of pneumonia, is not specific, since there are a number of other conditions that stimulate CRP synthesis, such as pulmonary infarction, inflammation and neoplasia.

In pneumonia, the close proximity of infection and tissue damage in the lung parenchyma to the pulmonary circulation produces an immunological stimulus for systemic CRP synthesis. The CRP response that is mediated by cytokines would be expected to be greater in pneumonia cases where there is more tissue damage [20]. When there is infective exacerbation of chronic obstructive airways disease (purulent bronchitis), it is sometimes difficult to exclude pneumonia on the basis of the radiological findings. This is because there are often chronic lung markings, or shadowing, due to a coexistent disease, such as pulmonary fibrosis or pneumoconiosis. Furthermore, it is important to distinguish between endobronchial and parenchymal infection, because the bacterial pathogens are often not the same and they may require different antibiotics. The most common bacterial pathogen in communityacquired pneumonia is $S$. pneumoniae, which is sensitive to amoxycillin, and on the other hand, atypical bacterial infection with Mycoplasma pneumoniae, Legionella pneumophila or Chlamydia pneumoniae may also occur, and these require the use of erythromycin. A more useful role for CRP is monitoring the response of pneumonia to antibiotic therapy [23].

In this study, CRP tests were used only as a qualitative determination (+ or -), and thus we were not able to deduce how many cases in the series were caused by virus, since the titers were not measured. These parameters gave high sensitivity and specificity when pleural fluid and/or serum samples were employed. However, pleural fluid samples were superior, with a predictive value (probability of disease in a patient with a positive CRP test) of $81.6 \%$, higher than the $61 \%$ determined for serum samples. Thus, the detection of $\mathrm{CRP}$ in pleural fluid may prove to be a rapid, practical, and accurate method to define bacterial pneumonia. Although the CRP assay is not cheap, it is quick to perform and could be used as a routine procedure.

\section{References}

1. Ballou S.P., Kushner I. C-Reactive protein response and the acute phase response. Adv Intern Med 1992;37:313-36.

2. Castell J.V., Gomez-Lechon M.J., David M., et al. Acute phase response of human hepatocytes: regulation of acute phase protein synthesis by interleukin-6. Hepatology 1990;12:1179-86.

3. Fleiss J.L. The measurement of interrater agreement. In: Statistical Methods for Rates and Proportions. 2 ed. New York. John Wiley \& Sons, 1981, p.212-36.

4. Fletcher R.M., Fletcher S.W., Wagner E.H. Clinical Epidemiology, the Essentials. Baltimore, Waverly, 1983.

5. Heffner J.E., Brown L.K., Barbieri C.A. Diagnostic value of tests that discriminate between exudative and transudative pleural effusions. Chest 1997;111:970-80. 
6. Isaacs D. Problems in determining the etiology of community-acquired childhood pneumonia. Pediatr Infect Dis J 1989;8:143-8.

7. Korppi M., Leinonen M., Makela P.H., Launiala K. Bacterial co-infection in children hospitalized with respiratory syncytial virus infection. Pediatr Infect Dis J 1989;8:687-92.

8. Korppi M., Kröger L. C-Reactive protein in viral and bacterial respiratory infection in children. Scand. J Infect Dis 1992;25:207-13.

9. Korppi M., Heiskanen-Kosma T., Jalonen E., et al. Aetiology of community-acquired pneumonia in children treated in hospital. Eur J Pediatr 1993; 152:24-30.

10. Korppi M., Heiskanen-Kosma T., Leinonen M. White blood cells, C-reactive protein and erythrocyte sedimentation rate in pneumococcal pneumonia in children. Eur Respir J 1997; 10:1125-9.

11. Kushner I., Ganapathi M., Schultz D. The acute phase response is mediated by heterologous mechanisms. Ann NY Acad Sci 1989;557:19-30.

12. Light R.W. Pleural effusion: the diagnostic separation of transudates and exudates. Ann Intern Med 1972;77:507-13.

13. McCarthy P.L., Frank A.L., Ablow R.C., et al. Value of the C-reactive protein test in the differentiation of bacterial and viral pneumonia. J Pediatr 1978;92:454-6.

14. Morley J.J., Kushner I. Serum C-reactive protein levels in disease. Ann NY Acad Sci 1982;389:406-18.

15. Nakano T., Chahinian A.P., Shinjo M., et al. Interleukin-6 and its relationship to clinical parameters in patients with malignant pleural mesothelioma. Br. J. Cancer 1998; 77:907-12.

16. Okamura J.M., Miyagi J.M., Terada K., et al. Potential clinical applications of C-reactive protein. J Clin Lab Anal 1990;4:231-5.

17. Requejo H.I.Z., Almeida R.G., Cadagrande S.T., et al. Dotenzyme-linked immunosorbent assay for detection of pneumococcal polysaccharide antigens in pleural fluid effusion samples. Comparison with bacterial culture, counterimmunoelectrophoresis and latex agglutination. Rev Inst Med Trop SP 1994;36(6):531-5.

18. Requejo H.I.Z., Guerra M.L.L.S., Santos M., Cocozza A.M. Immunodiagnoses of community-acquired pneumonia in childhood. J Trop Pediatr 1997;43:208-12.

19. Ribeiro M.A. C-Reactive protein: re-evaluation of a diagnostic laboratory test. Braz J Infect Dis 1997;1(5):212-25.

20. Smith R.P., Lipworth B.J. C-Reactive protein in simple community-acquired pneumonia. Chest 1995; 107:1028-31.

21. Turay Ü.Y., Yildrim Z., Türköz Y., et al. Use of pleural fluid C-reactive protein in diagnosis of pleural effusions. Resp Medicine2000;94:432-5.
22. Vidriales J.L.C., Antequera C.A. Use of pleural fluid Creactive protein in laboratory diagnosis of pleural effusions. Eur J Med1992;1:201-7.

23. Woodhead M.A., McFarlane J.T. Comparative clinical and laboratory features of legionella with pneumococcal and mycoplasma pneumonias. BrJ Dis Chest 1987;81:133-9. 